\title{
THE FRESHWATER CRAYFISH AUSTROPOTAMOBIUS PALLIPES (LEREBOULLET, 1858) IN LIGURIA, NW ITALY: IMPLICATIONS FOR MANAGEMENT AT THE REGIONAL LEVEL.
}

\author{
S. SALVIDIO*, M. MORI, A. LATTES, L. GALLI, A. ARILLO
}

DIP.TE.RIS., Università di Genova, Corso Europa 26, I-16132 GENOVA, Italia.

* corresponding author / auteur pour correspondance. E-mail : salvidio@dipteris.unige.it

\begin{abstract}
Since 1990, field surveys have been undertaken in Liguria to assess the distribution and status of Austropotamobius pallipes populations. In this region, crayfish stocks were found in three bioclimatic regions: Alpine, Mediterranean and Continental. Although epidemic diseases and invasive alien crayfish have been recorded, modifications of freshwater habitats have to be considered as the most significant threats to native crayfish stocks. Regarding management, the Regional Administration of Liguria proposed 18 Sites of Community Importance (SCl) containing crayfish populations, in the framework of the Habitats Directive (92/43/EEC). Since public managers need to take informed decisions in land-use management and conservation a numeric biodiversity map, composed by a georeferred database connected to a geographic information system (GIS), has been implemented. This regional system is composed by 22 different layers containing all the available information about the location of species and habitats of conservation interest. This system is now routinely used by regional administrators in environmental impact assessment. Finally, emphasis is placed on the need of promoting research programmes on the long-term monitoring of crayfish populations.
\end{abstract}

\section{L'ÉCREVISSE À PIEDS BLANCS AUSTROPOTAMOBIUS PALLIPES \\ (LEREBOULLET, 1858) EN LIGURIE, NW ITALIE : IMPLICATIONS POUR LA CONSERVATION À L’ÉCHELLE RÉGIONALE.}

\section{RÉSUMÉ}

En Ligurie, un inventaire sur la répartition de l'écrevisse à pattes blanches Austropotamobius pallipes est en cours depuis 1990. Actuellement, les stocks astacicoles sont présents dans les régions biogéographiques alpines, continentales et méditerranéennes. La présence d'écrevisses allochtones et de maladies parasitaires a été signalée, mais la dégradation des habitats naturels est sans doute la menace la plus importante pour l'espèce. Dans le cadre de la Directive Communautaire 92/43 « Habitats et Espèces ", l'Administration Régionale de la Ligurie a proposé 123 Sites d'Importance Communautaire (SIC), dont 18 contiennent des populations d'écrevisses. Du point de vue gestionnaire, tous les sites de $A$. pallipes ont été informatisés et inclus dans un Système 
Informatique Géographique (SIG) régional dans lequel les habitats et les espèces d'intérêt patrimonial sont localisés. Ce système est utilisé de façon routinière par les services techniques régionaux pour l'évaluation des projets d'aménagement du territoire. Enfin, on remarque la nécessité d'établir des protocoles scientifiques pour le suivi à long terme des populations d'écrevisses.

\section{INTRODUCTION}

Liguria is a NW Italian Administative Region with a surface of about $5400 \mathrm{~km}^{2}$ (Figure 1). This region is bordered by the Ligurian sea, the Maritime Alps, and the Apennines are close and parallel to the seacoast. Because of its geographic position and geomorphology, this territory occupies a transitional position between the Mediterranean and the Continental bioclimatic areas (BARBERIS et al., 1992; OZENDA and BOREL, 2000).

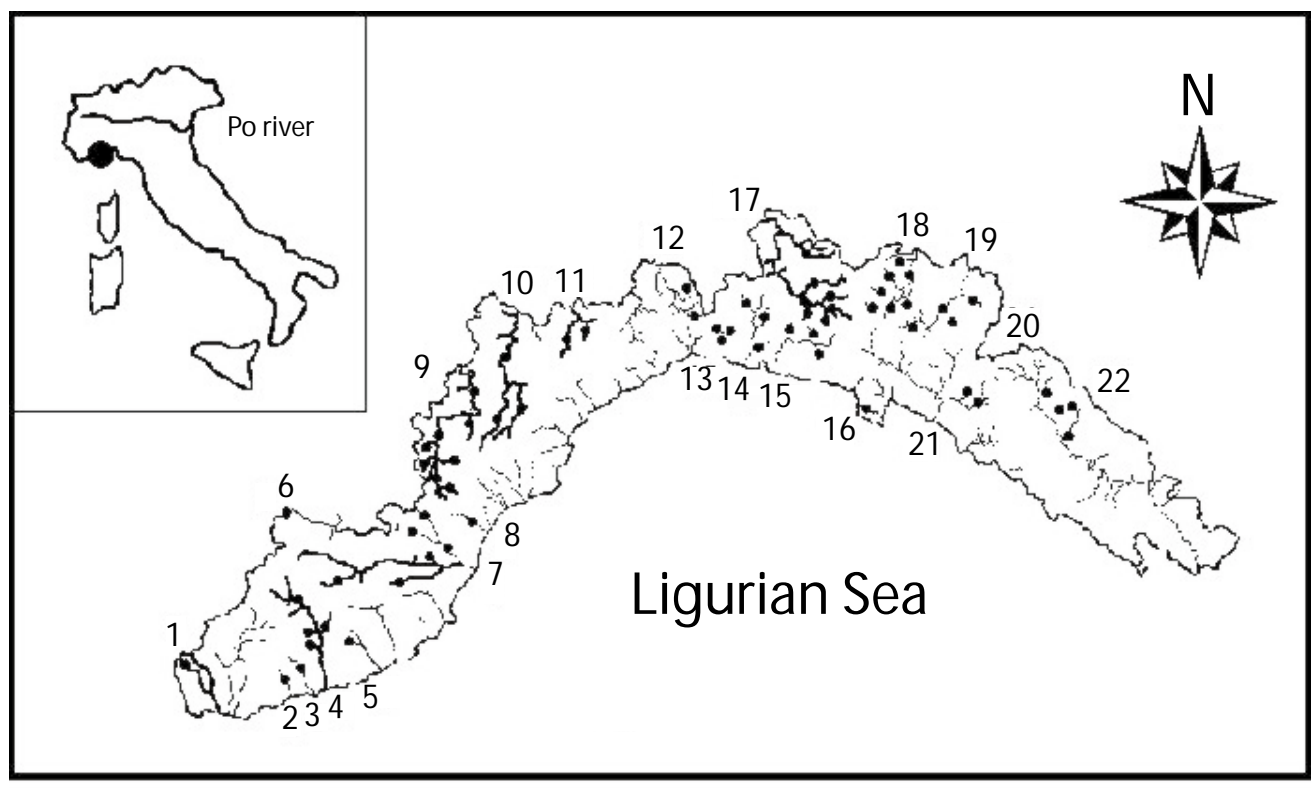

Figure 1

Distribution of Austropotamobius pallipes in Ligurian water basins. 1) Roja; 2) San Romolo; 3) Armea; 4) Argentina; 5) Prino; 6) Tanaro; 7) Arroscia; 8) Varatello; 9) Bormida di Millesimo; 10) Bormida di Spigno; 11) Erro; 12) Stura; 13) Chiaravagna; 14) Polcevera; 15) Bisagno; 16) Gentile; 17) Scrivia; 18) Trebbia; 19) Aveto; 20) Lago delle Lame; 21) Entella; 22) Vara. The thick lines indicate watercourses in which crayfish presence was mapped by VINCIGUERRA (1899).

\section{Figure 1}

Carte de répartition de Austropotamobius pallipes dans les bassins versants de Ligurie. 1) Roja ; 2) San Romolo ; 3) Armea ; 4) Argentina ; 5) Prino ; 6) Tanaro ; 7) Arroscia ; 8) Varatello ; 9) Bormida di Millesimo ; 10) Bormida di Spigno ; 11) Erro ; 12) Stura ; 13) Chiaravagna ; 14) Polcevera ; 15) Bisagno ; 16) Gentile ; 17) Scrivia ; 18) Trebbia ; 19) Aveto ; 20) Lago delle Lame ; 21) Entella ; 22) Vara. Le trait épais indique les cours d'eau où la présence d'écrevisses avait été signalée par VINCIGUERRA (1899). 
The first historical record of the presence of freshwater crayfish in Liguria dates back to the beginning of the $19^{\text {th }}$ century, when CASALIS (1833) reported the presence of " gamberi » (i.e. crayfish) in the Bormida stream, near of the village of Calizzano (Province of Savona). Later, VERANY (1846) and TARGIONI-TOZZETTI (1874) confirmed the presence of crayfish in Ligurian inland waters. The first Italian crayfish inventory was published by VINCIGUERRA in 1899. This paper, a national inquiry based on a questionnaire compiled by forestry officers, gave the first detailed distributional map of crayfish for the entire Italian peninsula. The mapping system used by VINCIGUERRA (1899), showed the presence of crayfish populations in well identifiable watercourses, becoming the obvious reference for all subsequent surveys in the country. Eighty years later, MANCINI (1986) published another national survey based on questionnaires compiled by Water Authorities. MANCINI (1986, p. 154) reported that in three out of four Provinces of Liguria (i.e. Imperia, Savona and Genova) crayfish populations were declining since 1970. Unfortunately, this author did not show detailed distributional maps as VINCIGUERRA (1899); thus, no comparison between the two studies is possible.

Only recently has the distribution of Austropotamobius pallipes been summarised at the regional level (SALVIDIO et al., 1993). As the correct management of this species implies the knowledge of distribution, status and main threats of crayfish stocks, we updated the previous survey and discussed baselines for further research on diffusion, conservation and management, in the framework of the recent international legislation.

\section{MATERIAL AND METHODS}

The present inventory is based upon official reports published by Water Authorities (AA VV, 1990, 1991, 1994, 1996a, b), specialised papers (MORI et al., 1996, 1998, 2000; MORI and SALVIDIO, 2000) and unpublished field observations personally verified by at least one of the authors. In this study, we did not map unpublished records obtained from Water Authorities, as in SALVIDIO et al. (1993). During our survey, crayfish were captured by hand, dipnet or trapped with baited traps. Each specimen was inspected macroscopically with a $3 X$ magnifying lens to verify its sanitary status. Only dead or dying crayfish were permanently removed from their habitat, preserved in $5 \%$ formaldehyde and carried to the laboratory, for further investigations. All records were georeferred using the official technical map of Liguria in scale 1:10 000, and implemented in a database related to a Geographic Information System (GIS) through MAPINFO software.

\section{RESULTS}

\section{Current distribution}

To date, several watercourses are known to be inhabited by crayfish populations and each year new sites are found, suggesting that the current inventory is not yet exhaustive. Figure 1 shows the distribution of Austropotamobius pallipes updated to December 2000. To give an historical perspective, all the localities mapped by VINCIGUERRA (1899) were surveyed, and all pre-1900 records were confirmed. Crayfish populations were found in several watercourses, both in Tyrrhenian and Adriatic catchments. Most records were from small streams with well oxygenated waters and rocky pools, although crayfish were found in rivers and ponds as well. The altitudinal distribution ranged from about $90 \mathrm{~m}$ a.s.l. in the Varatello stream (Toirano, Province of Savona) to $1050 \mathrm{~m}$ a.s.I. in the Lago delle Lame (Rezzoaglio, Province of Genova), a small isolated glacial lake, where the species was probably introduced by man. Crayfish populations appeared widespread in western and central Liguria, especially in watercourses that are tributaries of the Po river system. The species was rare in the Province of La Spezia (i.e. eastern Liguria), where the river crab Potamon fluviatile is found (CAPRA, 1953; BRAIDA et al., 2001). 


\section{Threats to extant populations}

In Liguria, only one alien crayfish species, the red swamp crayfish Procambarus clarkii, has become established in swampy areas along the Magra river (Province of La Spezia), where a control programme is operating (BRAIDA, 2000). At present, there is no close contact between $P$. clarkii and $A$. pallipes in the region. However, the possibility of an accidental or intentional diffusion of $P$. clarkii in watercourses inhabited by $A$. pallipes is possible, and should be prevented by all means.

Regarding the sanitary status the crayfish plague, caused by the fungus Aphanomyces astaci, has never been reported from Liguria (ALDERMAN, 1996), and no cases were observed in our 10-year field survey. Pathological data obtained on several populations in different parts of Liguria gave relatively low rates of bacterial or protist infestations, and in nine populations the infestation rate of the porcelaine disease, caused by the protozoan Thelohania contejeani, never exceeded 4\% (MORI and SALVIDIO, 2000). In the Arvigo basin (Province of Genova), thelohaniasis was monitored from 1994 to 2001, and the infestation rate remained extremely low and constant throught time, showing no overall directional trends (Spearman's correlation coefficient, $r_{s}=0.557, N=7, P>0.05$; Figure 2).

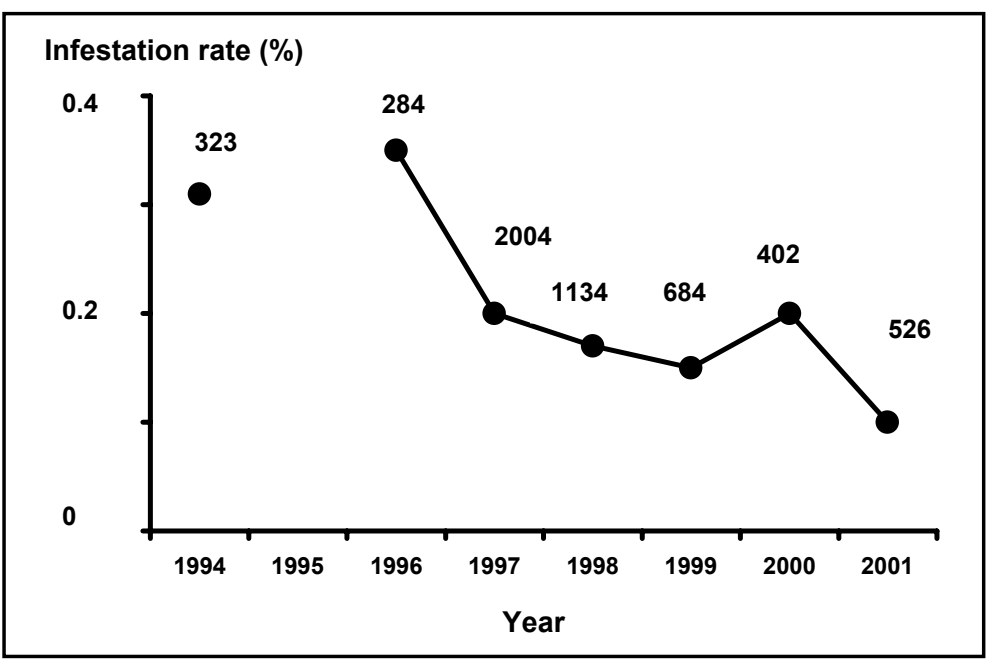

Figure 2

Infestation rate of thelohaniasis in crayfish from the Arvigo basin (Bisagno catchment, Province of Genova). Numbers indicate sample sizes.

\section{Figure 2}

Taux d'écrevisses infestées par thélohaniose dans le bassin de l'Arvigo (Province de Genova). Les échantillons sont indiqués.

\section{Conservation at the regional scale}

In Liguria, A. pallipes is totally protected according by the regional law (L.R. 4/92). In addition it is listed on Annex II and V of the EC Council Directive No. 92/43 " Habitats ", that plays a crucial role in the designation of Sites of Community Importance (SCl). When officially designated by the European Commission, these sites will become Special Areas of Conservation (SACs) in the framework of the European-wide network Natura 2000. In 1995, the Italian Ministry of Environment, in collaboration with Regional Administrations, submitted to the European Commission a national list of SCl. In Liguria, out of 123 proposed SCl, 17 contained freshwater crayfish populations, and in one case crayfish were discovered only in 1997, after the official submission of the list (Table I). 
Table I

List of Sites of Community Importance proposed by the regional administration of Liguria in which Austropotamobius pallipes populations are known. ${ }^{1}$ In this site, the species was discovered in 1997 after the presentation of the list.

\section{Tableau I}

Sites d'Importance Communautaire avec populations de

Austropotamobius pallipes proposés par l'Administration de Ligurie. ${ }^{1}$ Dans ce site, l'espèce a été recensée en 1997, après la présentation de la liste.

\begin{tabular}{|clc|} 
Natura 2000 Code & \multicolumn{1}{c|}{ Site of Community Importance } & Biogeographic region \\
\hline IT1314611 & M. Gerbonte & Alpine \\
IT1315503 & M. Carpasina & Mediterranean \\
IT1315806 & M. Nero - M. Bignone & Mediterranean \\
IT1321394 & Giovo Ligure & Mediterranean \\
IT1322304 & Rocca dell' Adelasia & Continental \\
IT1323014 & M. Spinarda - Rio Nero & Continental \\
IT1323112 & M. Carmo - M. Settepani & Alpine \\
IT1324011 & M. Ravinet - Rocca Barbena & Mediterranean \\
IT1330213 & Conglomerato di Vobbia & Continental \\
IT1330925 & Rio Pentemina & Continental \\
IT1332603 & Parco di Portofino' & Mediterranean \\
IT1331019 & L. Brugneto & Continental \\
IT1331104 & Parco dell' Aveto & Continental \\
IT1331124 & Rio Molini - Prato Fiorezza & Continental \\
IT1331402 & Beigua - M. Dente - Gargassa - Pavaglione & Mediterranean \\
IT1331721 & Val Noci - Torrente Geirato - Alpesisa & Continental \\
IT1342907 & M. Antessio - Chiusola & Mediterranean \\
IT1343527 & Canale Begarino & Mediterranean \\
\hline
\end{tabular}

The distribution of $A$. pallipes in Liguria (Figure 1) was implemented within the numeric biodiversity regional map using a georeferred data base connected to a geographic information system (GIS). This regional system is composed by 22 different layers containing all the available informations about the location of animals, plants and habitats of biological and conservation interest (MARGIOCCO and MARIOTTI, 2001).

\section{DISCUSSION}

\section{Present distribution and status}

Our regional survey confirmed all the historical records published by VINCIGUERRA (1899). Crayfish stocks were widespread all over the region with the exception of the Province of La Spezia (eastern Liguria) where the river crab is found. In this area, the present distribution of these two freshwater decapods is probably the result of a past interspecific competition, the crayfish being excluded from the lower parts of the streams by the ecologically dominant river crab (BARBARESI and GHERARDI, 1997). Unfortunately, the lack of historical records hinders the reconstruction of recent trends of crayfish populations at the regional scale. In addition, the current wide diffusion of $A$. pallipes could be due to translocation of crayfish stocks, since in the past they were frequently used for human consumption (SPITZY, 1979). 
Freshwater crayfish populations are threatened by several environmental, biological and anthropogenic impacts (HOLDICH and ROGERS, 1997). Recently, the introduction of non indigenous crayfish all over Europe is considered one of the main threats to the survival of native stocks (GHERARDI and HOLDICH, 1999; BARBARESI and GHERARDI, 2000). In Italy, these invasive decapods are now widespread, and in many cases they are becoming a pest contributing to the degradation and homogenization of inland aquatic habitats (GHERARDI et al., 1999). At present, the diffusion of non indigenous crayfish in Liguria is still limited and no contact between native and alien stocks has been reported.

For these reasons, the main hazards to extant Ligurian populations have to be considered as habitat modifications, and in particular those due to urban or industrial development, water abstraction and pollution (SALVIDIO et al., 1993).

\section{Conservation in the framework of the Directive 92/43/EEC}

In Liguria, the proposed list of $\mathrm{SCl}$ containing crayfish populations was consistent with the general purposes of the " Habitats » Directive, that aims to preserve biological diversity in all the biogeographic areas within the Europen territory. In any case, all crayfish populations and their habitats constitute objects of a strict conservation policy, and local Administrations should be aware of the relationships between land use, development and conservation. Indeed, public managers are more and more requiring operational tools to evaluate the impact of different land uses upon the natural landscape. In Liguria, the GIS implemented to respond to the provisions of the Directive, is now routinely used by regional Services to take "informed " decisions on land-use and in environmental impact assessment (EIA), according to national and regional legislations. In addition, as the Regional Administration recently adopted Article 6 of the Directive (EUROPEAN COMMISSION, 2000), this system will be used in assessing the compatibility of all kind of projects proposed within SCl and in the future within SACs.

\section{Perspectives for scientific research}

Article 1 of the Directive requires that conservation plans of SACs should be conceived on the basis of dynamic data indicating that habitats and species of conservation importance have been preserved on a long-term basis. For these reasons, the implementation of management plans assessing species status through long-term surveys has been suggested (VALENTIN-SMITH, 1998). Thus, basic research should address the question of crayfish monitoring at the regional scale, since little is known about the natural fluctuations in abundance and sanitary status of $A$. pallipes. Moreover, longterm surveys are necessary to distinguish negative trends (i.e. declines) from natural fluctuations often observed in wild populations, and to provide a scientific basis for detecting effects of environmental impacts and changes in the species status (SPELLERBERG, 1991). Indeed, intensive field research will be required to assess whether or not changes in abundance and diffusion of crayfish populations are occurring at different geographic scales. Without knowing this, future efforts to monitor the effectiveness of management initiatives will be probably constrained.

\section{AKNOWLEDGMENTS}

The Provinces of Genova, Imperia, La Spezia and Savona authorized crayfish surveys. Thanks are due to our friends Elena Casarino, Paolo Cresta, Giuliano Doria, Gianluca Grandoni, Yuri Pretoni, Edoardo Razzetti and to all our students that participated during the many years of field work. 


\section{REFERENCES}

AA VV, 1990. Carta ittica della Provincia della Spezia. La Spezia, $172 \mathrm{p}$.

AA VV, 1991. Carta ittica della Provincia di Savona. Savona, 304 p.

AA VV, 1994. Monitoraggio dello stato dei corsi d'acqua della provincia basato su metodi biologici. Stato delle acque interne correnti della Provincia di Genova. Risultati dell'indagine 1990-1991. Genova, $410 \mathrm{p}$.

AA VV, 1996a. Monitoraggio dello stato dei corsi d'acqua della provincia basato su metodi biologici. Stato delle acque dei bacini del levante. Indagine fino al 1996. Genova, $259 \mathrm{p}$.

AA VV, 1996b. Monitoraggio dello stato dei corsi d'acqua della provincia basato su metodi biologici. Stato delle acque dei bacini del ponente. Indagine fino al 1996. Genova, $232 \mathrm{p}$.

ALDERMAN D.J., 1996. Geographical spread of bacterial and fungal diseases of crustacean. Rev. Sci. Tech. Off. Int. Epiz., 15 (2), 603-632.

BARBARESI S., GHERARDI F., 1997. Italian freshwater decapods: exclusion between the crayfish Austropotamobius pallipes (Faxon) and the river crab Potamon fluviatile (Herbst). Bull. Fr. Pêche Piscic., 347, 731-747.

BARBARESI S., GHERARDI F., 2000. The invasion of the alien crayfish Procambarus clarkii in Europe, with particular reference to Italy. Biological Invasions, 2, 259-264.

BARBERIS G., PECCENINI S., PAOLA G., 1992. Notes on Quercus ilex L. in Liguria. (NW Italy). Vegetatio, 99-100, 35-50.

BRAIDA L., 2000. II gambero Procambarus clarkii (Girard, 1852) in provincia della Spezia. In : NARDELLI R. (ed.). Fauna 2000 - Indagini sulla fauna del comprensorio provinciale spezzino. Luna Editore, La Spezia, $63 \mathrm{p}$.

BRAIDA T., MORI M., SALVIDIO S., 2001. Note sulla distribuzione di Potamon fluviatile (Herbst) (Crostacea, Decapoda, Potamonidae) in Liguria. Doriana, suppl. Ann. Museo Civico St. nat. " G. Doria », Genova, 7 (320), 1-7.

CASALIS G., 1833. Dizionario geografico, storico, statistico, commerciale degli Stati di Sua Maestà il Re di Sardegna. Torino, $278 \mathrm{p}$.

CAPRA F., 1953. II granchio di fiume Potamon edule (Latr.) in Liguria. Doriana, suppl. Ann. Museo Civico St. nat. « G. Doria », Genova, 1 (44), 1-7.

EUROPEAN COMMISSION, 2000. Managing Natura 2000 Sites: the provisions of Article 6 of the " Habitats Directive " 92/43/ECC. Office for the official publications of the European Communities, Luxembourg, $69 \mathrm{p}$.

GHERARDI F., HOLDICH D.M. (Eds.), 1999. Crayfish in Europe as alien species. How to make the best of a bad situation? Rotterdam (Balkema: Crustacean Issues, Vol. II), $299 \mathrm{p}$.

GHERARDI F., BALDACCINI G.N., ERCOLINI P., BARBARESI S., DE LUISE G., MAZZONI D., MORI M., 1999. The situation in Italy. In: GHERARDI F., HOLDICH D.M. (Eds.), Crayfish in Europe as alien species. How to make the best of a bad situation?, 161-192, Balkema, Rotterdam.

HOLDICH D.M., ROGERS W.D., 1997. The white-clawed crayfish, Austropotamobius pallipes, in Great Britain and Ireland with particular reference to its conservation in Great Britain. Bull. Fr. Pêche Piscic., 347, 597-616.

MANCINI A., 1986. Astacicoltura. Allevamento e pesca dei gamberi d'acqua dolce. Edizioni Calderini, Bologna, $180 \mathrm{p}$.

MARGIOCCO C., MARIOTTI M. (Eds.), 2001. Progetto Interreg IIC MEDOCC. Basi di dati e Cartografia della Biodiversità. Rapporto finale parte italiana. Cosenza, $212 \mathrm{p}$.

MORI M., SALVIDIO S., 2000. The occurrence of Thelohania contejeani Henneguy, a microsporidian parasite of the crayfish Austropotamobius pallipes (Lereboullet), in Liguria Region (NW Italy). Journal of Limnology, 59 (2), 165-167.

MORI M., SALVIDIO S., ISOLA G., CRESTA P., 1996. Struttura demografica di quattro popolazioni del gambero d'acqua dolce Austropotamobius pallipes (Lereboullet), della Liguria (Italia). Annali Museo Civico di Storia Naturale «G. Doria », Genova, 91, 341-354. 
MORI M., SALVIDIO S., CRESTA P., 1998. Size structure, relative growth and sanitary condition of a crayfish population (Austropotamobius pallipes) living in rockypools. Spixiana, 21 (2), 135-144.

MORI M., ROSSO E., SALVIDIO S., 2000. Presenza e incidenza delle branchiobdelle (Annelida, Branchiobdellidae) nelle popolazioni astacicole liguri. Annali Museo Civico di Storia Naturale “G. Doria », Genova, 93, 211-224.

OZENDA P., BOREL J.L., 2000. An ecological map of Europe: why and how? C.R. Acad. Sci. Paris, Sciences de la Vie, 323, 983-994.

SALVIDIO S., CRESTA P., DORIA G., 1993. Preliminary survey on the distribution of freshwater crayfish Austropotamobius pallipes in Liguria, N. W. Italy. Crustaceana, 65 (2), 218-221.

SPELLERBERG I.F., 1991. Monitoring ecological change. Cambridge University Press, Cambridge, $334 \mathrm{p}$.

SPITZY R., 1979. The prehistoric man as crayfish transplater. Freshwater Crayfish, 4, 221-226.

TARGIONI-TOZZETTI A., 1874. La pesca in Italia. Annali del Ministero di Agricoltura, Industria e Commercio. Tipografia del R. Istituto Sordo-muti, Genova, 685 p.

VALENTIN-SMITH G., 1998. Guide méthodologique des documents d'objectifs Natura 2000. Reserves Naturelles de France / Atelier Technique des Espaces Naturels, Quétigny, $144 \mathrm{p}$.

VERANY G.B., 1846. Crostacei. In: SPINOLA M., Descrizione di Genova e del Genovesato. 1. Tipografia Ferrando, Genova, $180 \mathrm{p}$.

VINCIGUERRA D., 1899. I gamberi d'acqua dolce in Italia. Relazione presentata alla Commissiome Consultiva della Pesca nella sessione del maggio 1898. Annali di Agricoltura, 219, 1-25. 